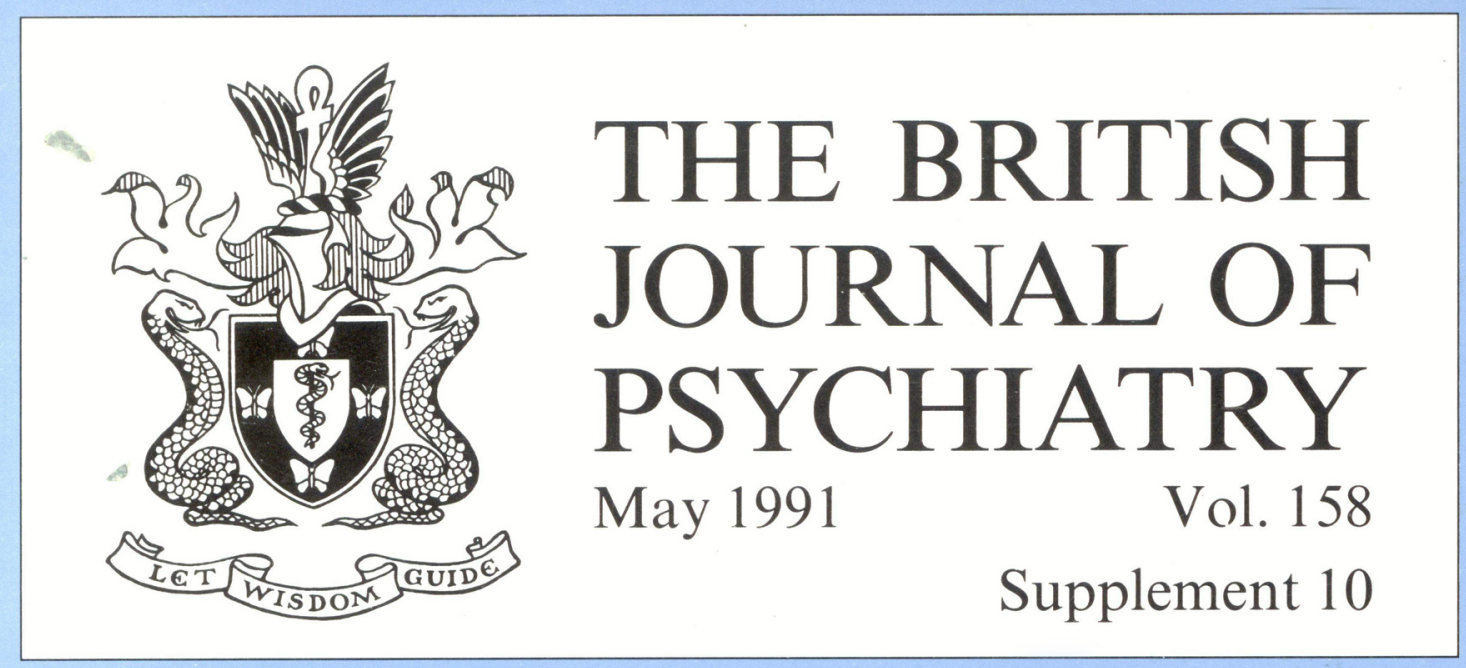

\title{
Women and Mental Health
}

Edited by

Women and Mental Health International Conference Committee

150 Years of British Psychiatry 1841-1991

Published by The Royal College of Psychiatrists 


\section{THE BRITISH \\ JOURNAL OF PSYCHIATRY}

SUPPLEMENT NUMBER 10

VOLUME 158, 1991

\section{Women and Mental Health}

Edited by

THE WOMEN AND MENTAL HEALTH

INTERNATIONAL CONFERENCE COMMITTEE 


\section{The British Journal of Psychiatry}

Published monthly. Founded in 1853 as the Asylum Journal and known as the Journal of Mental Science from 1855 to 1963

\section{Editor: Hugh Freeman}

\section{Senior Associate Editor}

Alan Kerr

\section{Associate Editors}

Dora Black, Sidney Crown, Julian Leff, Sir Martin Roth,

Peter Tyrer

\section{Assistant Editors}

Mohammed Abou-Saleh, Peter Bruggen, Patricia Casey, Alexander Kellam, Stuart Montgomery, Catherine Oppenheimer, Ian Pullen, Rosalind Ramsay, Henry Rollin, Oliver Russell, George Stein, Digby Tantam, Greg Wilkinson, Stephen Wilson

\section{Publications Manager \\ Dave Jago}

\section{Scientific Editor}

Ralph Footring

\section{Bulletin Manager \\ Elaine Millen}

\section{Assistant Scientific Editor}

Katharine Blanford

\section{Editorial Assistants \\ Judy Ashworth, Christina Connolly}

$\circledast^{\mathrm{TM}}$ The paper used in this publication meets the minimum requirements of American National Standard for Information Sciences-Permanence of Paper for Printed Library Materials. ANS1 Z39. $48-1984$

Typeset by Dobbie Typesetting, Tavistock, Devon. Printed by Henry Ling Ltd, The Dorset Press, 23 High East Street, Dorchester, Dorset DT1 1HD (tel. 0305-251 066).

(C) 1991 The Royal College of Psychiatrists

\section{Subscriptions}

Non-members of the College should contact the British Journal of Psychiatry Subscription Department, The Royal Society of Medicine, 1 Wimpole Street, London W1M 8AE. Annual subscription rates for 1991 (12 issues post free) are as follows:

UK: institutions $£ 115$, individuals $£ 95$ US: institutions $\$ 285$, individuals $\$ 175$ Elsewhere: institutions $£ 140$, individuals $£ 112$

Single copies of the Journal are $£ 10, \$ 20$ (post free)

Payment should be made out to the British Journal of Psychiatry.

Queries from non-members about missing or faulty copies should be addressed within six months to the same address; similar queries from College members should be addressed to the Registration Department, The Royal College of Psychiatrists, 17 Belgrave Square, London SW1X 8PG.

\section{Advertising}

Correspondence and copy should be addressed to Peter T. Mell, Advertising Manager, PTM Publishers Ltd, 282 High Street, Sutton, Surrey SM1 1PQ (tel. 081-642 0162, fax 081-643 2275).

US Mailing Agents: Mercury Airfreight International Ltd. Inc., 2323 Randolph Avenue, Avenel, NJ 07001.

Back issues published before 1988 may be purchased from William Dawson \& Sons Ltd, Cannon House, Folkestone, Kent, England (tel. 0303-850-101). 


\section{Contents}

Introduction

LYN PILOWSKY, GERALDINE O'SULLIVAN, RAJINI RAMANA, ELENI PALAZIDOU and PARIMALA MOODLEY

Emerging issues in medical ethics

CAROL C. NADELSON

Issues for women in the development of mental health services

FIONA SUBOTSKY

Depression in women

E. S. PAYKEL

Psychotropic drug prescribing in women

HEATHER ASHTON

Alcohol and drug misuse among women-an overview

EDNA OPPENHEIMER

Life stress and post-partum psychosis: a preliminary report

M. N. MARKS, A. WIECK, S. A. CHECKLEY and R. KUMAR

Women as perpetrators and victims of crime. A sociological perspective

FRANCES M. HEIDENSOHN

Adult sequelae of child sexual abuse

CAROL SHELDRICK

Sexual abuse, disordered personality and eating disorders

L. McCLELLAND, L. MYNORS-WALLIS, T. FAHY and J. TREASURE

Gender differences in carers of dementia sufferers

ROBIN G. MORRIS, ROBERT T. WOODS, KATH S. DAVIES and LORNA W. MORRIS

Sex differences in service usage in long-term psychiatric care. Are women adequately served?

RACHEL E. PERKINS and LEN A. ROWLAND

Where do people with long-term mental health problems live?

ALISON M. CONNING and L. A. ROWLAND

Psychology and psychopathology in women-a psychoanalytic perspective

ESTELA V. WELLDON 